NASA/TM-1999-209188

ARL-TR-1998
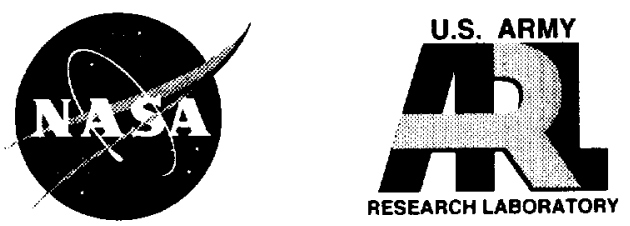

\title{
Evaluation of Carburized and Ground Face Gears
}

David G. Lewicki and Robert F. Handschuh

U.S. Army Research Laboratory, Glenn Research Center, Cleveland, Ohio

Gregory F. Heath and Vijay Sheth

The Boeing Company, Mesa, Arizona

Prepared for the

55th Annual Forum

sponsored by the American Helicopter Society

Montreal, Quebec, Canada, May 25-27, 1999

National Aeronautics and

Space Administration

Glenn Research Center 


\section{Acknowledgments}

The authors wish to thank Dr. William J. Scheuren of the Defense Advanced Research Projects Agency for his valuable contribution to the Technology Reinvestment Program "Development of Face Gear Technology

for Industrial and Aerospace Power Transmission".

Available from

NASA Center for Aerospace Information

7121 Standard Drive

Hanover, MD 21076

Price Code: A03
National Technical Information Service 5285 Port Royal Road Springfield, VA 22100

Price Code: A03 


\title{
Evaluation of Carburized and Ground Face Gears
}

\author{
David G. Lewicki and Robert F. Handschuh \\ U.S. Army Research Laboratory \\ National Aeronautics and Space Administration \\ Glenn Research Center \\ Cleveland, Ohio
}

\author{
Gregory F. Heath and Vijay Sheth \\ The Boeing Company \\ Mesa, Arizona
}

\begin{abstract}
Experimental durability tests were performed on carburized and ground AISI 9310 steel face gears. The tests were in support of a Defense Advanced Research Projects Agency (DARPA) Technology Reinvestment Program (TRP) to enhance face-gear technology. The tests were conducted in the NASA Glenn spiral-bevelgear/face-gear test facility. Tests were run at $2300 \mathrm{rpm}$ face gear speed and at loads of $64,76,88,100$, and 112-percent of the design torque of $377 \mathrm{~N}-\mathrm{m}$ (3340 in-lb). The carburized and ground face gears demonstrated the required durability when run for tenmillion cycles at each of the applied loads. Proper installation was critical for the successful operation of the spur pinions and face gears. A large amount of backlash produced tooth contact patterns that approached the inner-diameter edge of the face-gear tooth. Low backlash produced tooth contact patterns that approached the outer-diameter edge of the facegear tooth. Measured backlashes in the range of 0.178 to $0.254 \mathrm{~mm}(0.007$ to $0.010 \mathrm{in})$ produced acceptable tooth contact patterns.
\end{abstract}

\section{Introduction}

Designers are constantly searching for ways to reduce rotorcraft drive system weight. Reduced weight can increase payload, performance, or power density of current and future systems. One example of helicopter transmission weight reduction was initiated as part of the United States Army Advanced Rotorcraft Transmission program. This example used a splittorque, face-gear configuration concept [1]. Compared to a conventional design with spiral-bevel gears, the split-torque, face-gear design showed substantial weight savings benefits. Also, the use of face gears allows a wide range of possible configurations with technical and economic benefits [2].
Historically, face gears have been used to transfer light loads or angular motion between intersecting shafts (usually at right angles) such as in positioning mechanisms. Standards [3] as well as examples of research contributions [4] exist for this type of application. There is, however, a lack of experience with respect to design guidelines, stress allowables, and manufacturing capabilities for face-gear use in high-speed, high-load, applications such as helicopter rotor drive systems. Recent studies have been performed to advance the analytical capabilities relating to face-gear design [5-8]. These studies considered face-gear geometry, size limitation factors, tooth contact analysis, kinematics, and transmission error analysis. Experimental testing has also been performed to demonstrate feasibility and investigate failure modes of shaper-cut face gears [9-10]. These studies identified the need for face gears made from high-strength, carburized steels in order to obtain the required durability when subjected to a high-speed, high-load environment. When using carburized steels, there is a requirement to grind the gears to compensate for heat treatment distortion in order to obtain high-accuracy tooth geometry. However, there is currently no machine available that will grind face gears.

A new initiative has begun in Europe to investigate and advance the use of face gears in aerospace transmissions [11]. In the United States, a Defense Advanced Research Projects Agency (DARPA) Technology Reinvestment Program (TRP) was established to further enhance face-gear technology. The objective of the DARPA program is to develop a grinding procedure for face gears as well as design and demonstrate the proof-of-concept of a concentrically-arranged split-torque, face-gear transmission configuration $[12]$. A grinding

Copyright (C) 1999 by the American Helicopter Society, Inc. All rights reserved. 
procedure was developed based on a continuous grinding method using a worm grinding wheel. Prototype carburized and ground AISI 9310 steel face gears were fabricated as part of this program.

The objective of this work is to describe the preliminary results of the experimental tests performed on the carburized and ground AISI 9310 steel face gears. Face gears were tested in the NASA Glenn spiral-bevel-gear/face-gear facility. Basic facegear design, test facility, setup procedures, testing procedures, and test results are described.

\section{Face Gear Applications in Helicopter Transmissions}

Figure 1 shows the split-torque, face-gear transmission developed during the U.S. Army Advanced Rotorcraft Transmission (ART) program [1]. For this configuration, an involute spur

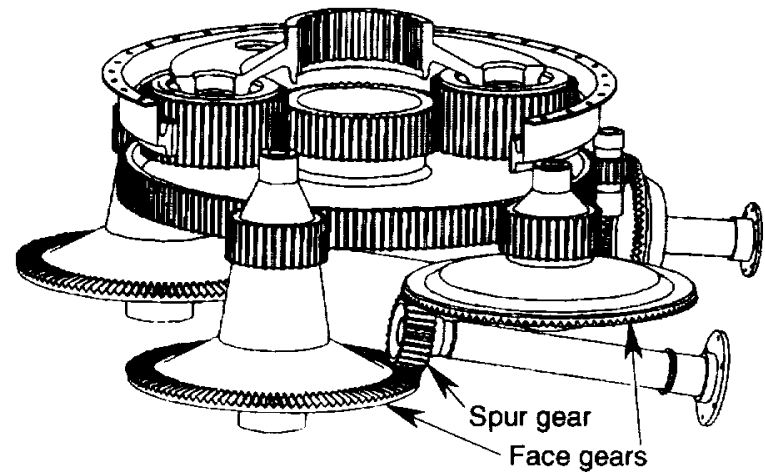

Figure 1. Split-torque, face-gear transmission from ART program [1].

gear drives both an upper face gear and lower face gear. These face gears are connected to spur gears which drive a large bull gear. By splitting the power flow in these two paths, smaller components can be utilized which leads to reduced weight. Compared to spiral-bevel gears, face gears allow the use of a simpler, less expensive, involute spur pinion. In addition, the pinions do not produce axial forces and have less axial misalignment restrictions than spiralbevel gears. It was estimated that a 40-percent weight reduction resulted from the split-torque, facegear design compared to a conventional design. The conventional design weight used for comparison above was based on a parametric upscale of transmission design technology existing at that time.
A design configuration which can be installed in existing aircraft much more readily than the preceding ART design is shown in Figure 2. This is

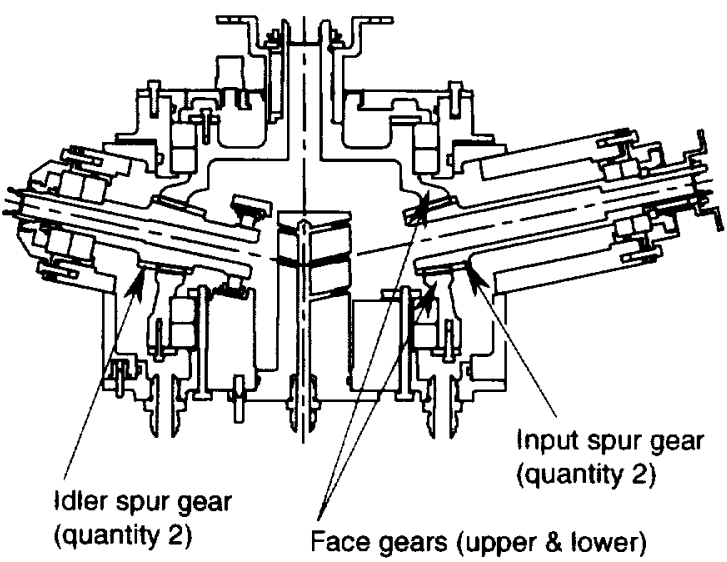

Figure 2. Split-torque, face-gear transmission from TAP program [12].

a concentric, split-torque, face-gear design developed during the DARPA Technology Reinvestment Program [12]. This reduced-scale test gearbox will be used in proof-of-concept test evaluations. For this concept, an involute spur gear also drives a pair of face gears and the power flow is split in two. For the upper face gear, the power flow is direct from the input spur gear to the face gear. For the lower face gear, however, the power flow is from the input spur gear through the lower face gear, to an idler spur gear, and then the upper face gear. This configuration allows a large power capacity in a relatively small package. Assuming a full size production design, this concept has an estimated weight savings of 25-percent compared to a modern technology conventional design. These two examples show the potential benefits for the use of face gears in helicopter transmissions.

\section{Test Facility}

The experiments reported in this report were tested in the NASA Glenn spiral-bevel-gear/face-gear test facility. An overview sketch of the facility is shown in Figure 3a and a schematic of the power loop in shown in Figure 3b. The facility operates in a closedloop arrangement. A spur pinion drives a face gear in the test (left) section. The face gear drives a set of helical gears, which in turn, drive a face gear and spur pinion in the slave (right) section. The pinions 


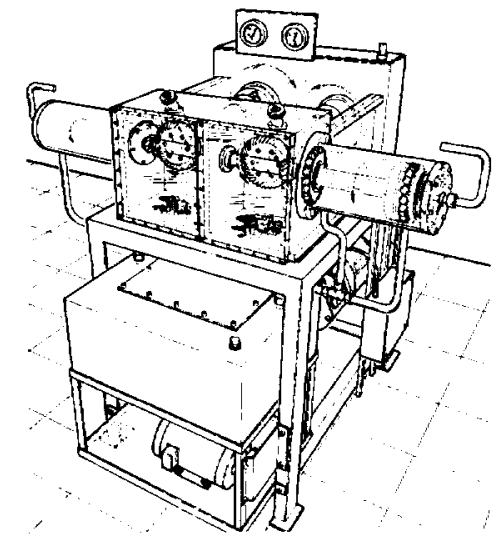

a) Overview of facility.

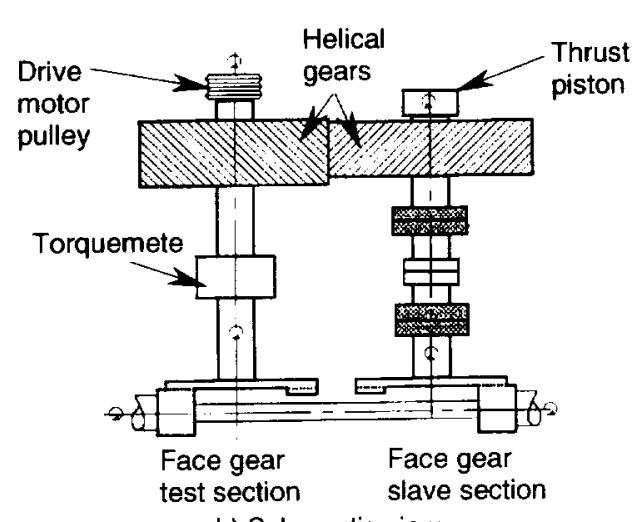

b) Schematic view.

Figure 3. NASA Glenn spiral-bevel-gear / face-gear test facility.

of the slave and test sections are connected by a cross shaft, thereby closing the loop. Torque is supplied in the loop by a thrust piston which exerts an axial force on one of the helical gears. A 75-kW (100-hp) DC drive motor, connected to the loop by $\mathrm{V}$-belts and pulleys, controls the speed as well as provides power to overcome friction. The facility has the capability to operate at $560 \mathrm{~kW}(750 \mathrm{hp})$ and $20,000 \mathrm{rpm}$ pinion speed. A torquemeter in the loop measures torque and speed. The facility is also equipped with thermocouples, oil flow meters, pressure transducers. and accelerometers.

The gears and bearings of the facility are lubricated and cooled by a pressurized oil system. The lubricating fluid used was a synthetic base helicopter transmission oil conforming to the DOD-L-85734 specification. The test pinions and face gears were lubricated by jets which radially directed oil into the roots of the teeth on both the into-mesh and out-ofmesh sides. The nominal oil supply pressure was $552 \mathrm{KPa}(80 \mathrm{psi})$ and the nominal flow rate was $2.6 \mathrm{l} / \mathrm{min}(0.7 \mathrm{gpm})$ for both the test section and slave section. Oil inlet temperature was set at $74{ }^{\circ} \mathrm{C}$ $\left(165^{\circ} \mathrm{F}\right)$. In addition, the oil system was equipped with a chip detector as well as a three-micron filter.

\section{Face Gear Grinding Setup}

The face gears used in the current tests were precision ground using a true generating method. The goal was to produce face gears having a quality of American Gear Manufacturers Association (AGMA) Class 12 or better. The method used employed a worm thread grinding wheel to generate

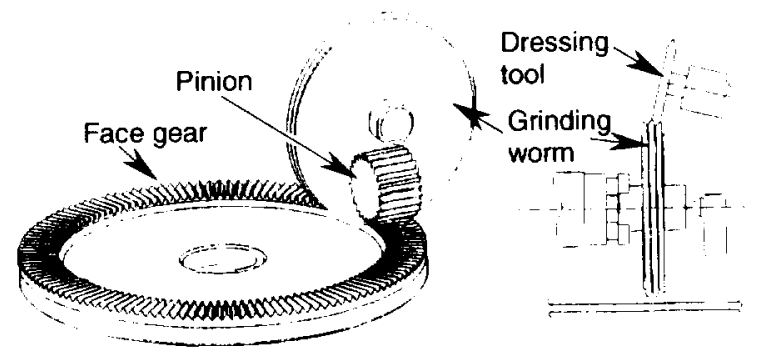

Figure 4. Face-gear grinding setup.

the face gear teeth in a setup similar to that shown in Figure 4. The worm wheel rotational axis was located perpendicular to the face gear axis at an offset distance. During grinding, the worm rotated about its axis as it translated across the face gear teeth along a nearly radial line. The translation was at a small angle to the true radial line and related to the lead angle of the worm. The face gear work piece also rotated slowly during grinding so that all teeth were generated synchronously after multiple turns of the face gear as the grinding worm slowly translated inward. An effective method of redressing the grinding wheel (without tooth undercutting) during the above process was also developed.

The face gears were ground on a four-axis machine incorporating the basic setup described above. The first development gears experienced grinding burns as process parameters were being adjusted. Other difficulties included tooth facets and rough surface finishes. Eventually, face gears of AGMA Class 11 quality were made for the tests. The experience with the setup used validated the process but indicated that a better machine is required to obtain the gear quality needed. Deficiencies encountered included limited machine grinding speed, excessive machine deflections, and control-loop errors inherent in older vintage machines. The machine capability for making larger face gears (desired for aerospace use) was limited as well. Current work is underway to develop a full CNC five-axis grinding machine for face gears. 


\section{Test Gears}

The design parameters for the pinions and face gears used in the tests are given in Table 1. A photograph of the test specimens is shown in Figure 5. This set was a hybrid between the ART program design and the TRP design. The set had a module of $2.54 \mathrm{~mm}$ (diametral pitch of 10 teeth/in) and a reduction ratio of 4.059:1. The face width of the face gears was $15.7 \mathrm{~mm}(0.620 \mathrm{in})$. The face width of the spur pinions was $32.6 \mathrm{~mm}$ (1.285 in). The shaft angle was $90 \mathrm{deg}$ to accommodate the facility. The pinions were made from carburized and ground AISI 9310 steel using standard aerospace practices. The face gears were made from the same material and manufactured using the grinding procedure previously mentioned.

Table 1. Test Gear Design Data

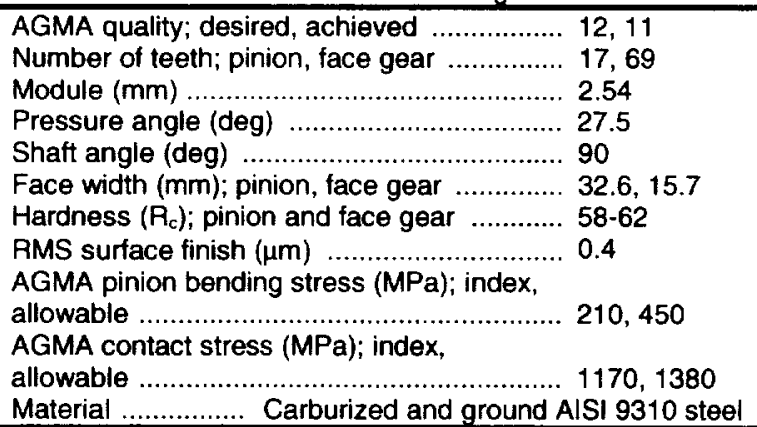

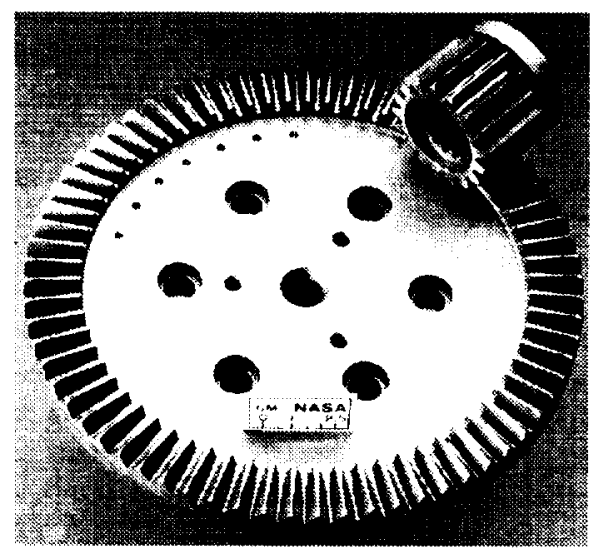

Figure 5. Test spur pinion and face gear.

The 100-percent design torque for the face gears was defined as $377 \mathrm{~N}-\mathrm{m}$ (3340 in-lb). This produced the same magnitude of contact stress as the face gears of the TRP concentric, split-torque transmission configuration at it's 100-percent design load [12]. For the test gears, the calculated contact stress at $377 \mathrm{~N}$-m torque was $1170 \mathrm{MPa}(170 \mathrm{ksi})$ based on
Hertz theory. The calculated pinion bending stress at $377 \mathrm{~N}$-m torque was $210 \mathrm{MPa}(30 \mathrm{ksi})$ based on standard AGMA calculations and using an effective face-gear face width. The allowables stated in the table are those commonly accepted for AISI 9310 carburized and ground spur gears.

Due to the manufacturing problems previously mentioned, the face gears actually produced by the grinding procedure described above were not up to aerospace quality standards. The teeth had a

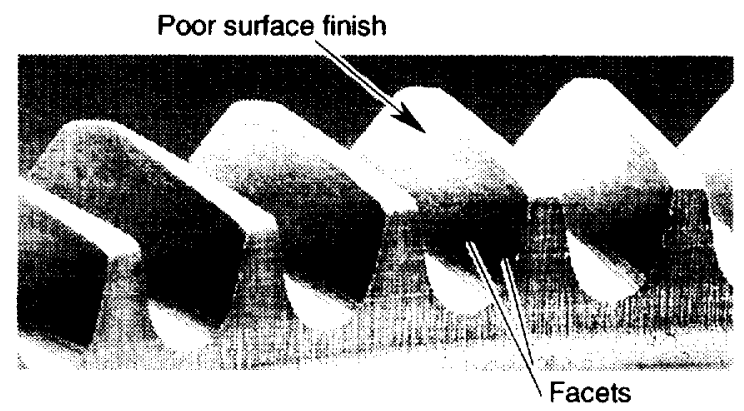

Figure 6. Development problems with initial ground face gear.

relatively poor surface finish as well as faceted areas (Figure 6). In order to improve the surface finish, the teeth were subjected to a super-finish process [13]. In this process, the gears were immersed in a container of small zinc chips, water, and aluminum oxide powder. The container was vibrated for a number of hours and the grade of oxide powder was increased in fineness in several stages. Figure 7 shows a face gear after such a process. Although

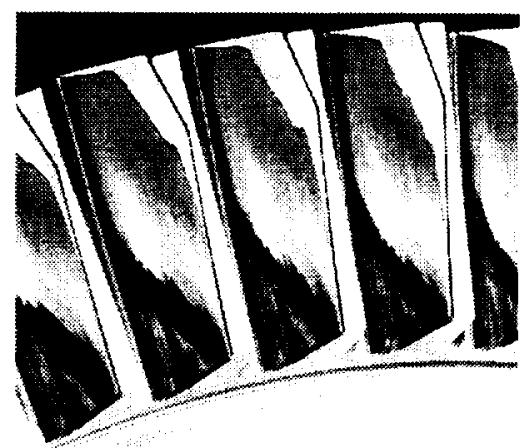

Figure 7. Super-finished face gear.

actual surface roughness measurements for the face gears tested were not available at the time, it was reported in [13] that a four to six-times improvement in surface finish was achieved on those specific gears studied. 


\section{Test Gear Installation Procedures}

Although not as stringent as for spiral-bevel gears. proper pinion and face gear installation is crucial for successful operation. The installation procedure for the gears tested was as follows. First, the test-side pinion and face gear were installed in the facility (with no cross shaft connected to the pinion). The pinion was locked to ground and backlash measurements were taken for the mesh. A dial indicator was installed at the center of the face gear tooth, the face gear was manually rotated back and forth, and the backlash was recorded. After completion, marking compound was applied to the pinion and face gear teeth. No-load contact pattern checks were performed by manually rotating the pinion/face-gear assembly. If necessary, the shim located behind the face gear, which moves the face gear in the axial direction, was adjusted to achieve the proper backlash and contact pattern. This process was then repeated for the slave-side pinion/face-gear mesh. After proper shimming was achieved, the cross shaft was installed. Marking compound was then re-applied to all the pinions and gears and a loaded static roll test was performed. This was done by applying a moderate torque in the loop, manually rotating the complete assembly, and photographing the contact patterns. Figure 8 shows a typical example of a tooth contact pattern check for a loaded static roll test. Again, the objective of this procedure

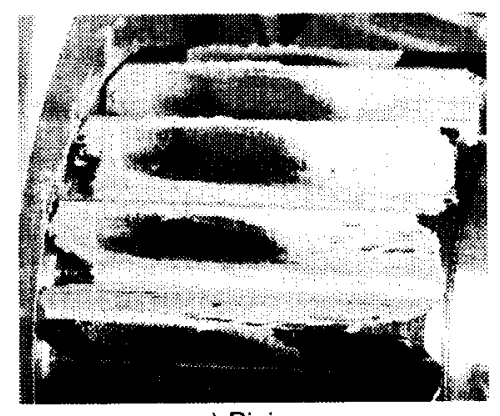

a) Pinion.

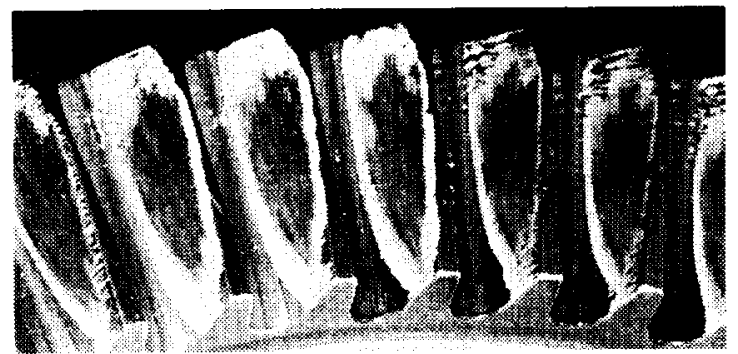

b) Face gear.

Figure 8. Typical tooth contact pattern checks from loaded static roll tests during installation. was to ensure the proper shimming to produce a tooth contact pattern that was centered on the pinion and face-gear teeth in order to avoid edge loading.

At the start of the project, it was unclear as to the proper value of shim that would produce the required backlash and contact pattern. To gain experience, a study was conducted to determine the effect of shimming on backlash and contact pattern. Here, various shims were installed while backlash and pattern checks were measured for the test and slave sections using the procedure described above. Figure 9 documents the effect of shimming on hacklash. It should be noted that there was some
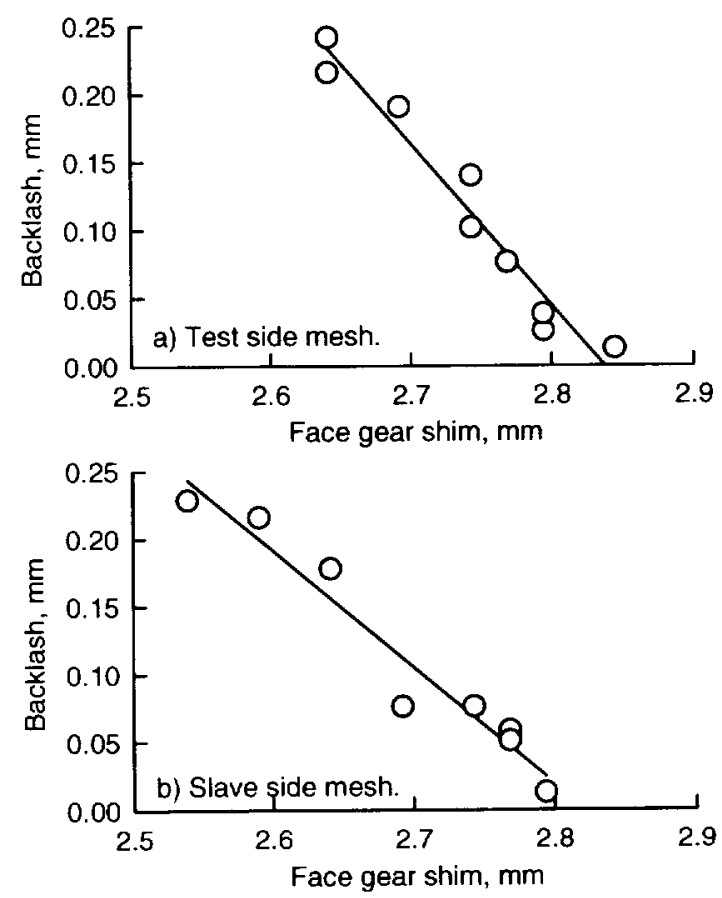

Figure 9. Effect of face-gear shimming on tooth backlash.

variability in the hacklash measurement. Overall, there appeared to be a linear relationship between shimming and backlash for the selected range presented. Figure 10 shows the effect of backlash on tooth contact pattern. The results depicted are for the test side, but a similar trend resulted for the slave side also. Note that the figure contains hand-drawn sketches of the contact pattern. The purpose is not to quantitatively define the required magnitude of backlash, but to show an important trend in the installation process. If the backlash is too loose (higher number), the tooth contact approaches the inner-diameter edge of the face gear, possibly leading to edge contact. If the backlash is too tight (lower 
Table 2. Test operating conditions.

\begin{tabular}{|c|c|c|c|c|c|c|c|c|}
\hline \multirow[b]{2}{*}{ Test No. } & \multirow[b]{2}{*}{$\begin{array}{l}\text { Face-gear } \\
\text { speed (rpm) }\end{array}$} & \multirow[b]{2}{*}{$\begin{array}{c}\text { Face-gear } \\
\text { torque }(\mathrm{N}-\mathrm{m})\end{array}$} & \multirow[b]{2}{*}{$\begin{array}{c}\text { Pinion, } \\
\text { million cycs }\end{array}$} & \multirow[b]{2}{*}{$\begin{array}{l}\text { Face-gear, } \\
\text { million cycs }\end{array}$} & \multicolumn{2}{|c|}{ Test section } & \multicolumn{2}{|c|}{ Slave section } \\
\hline & & & & & $\begin{array}{c}\text { Pinion } \\
\text { S/N }\end{array}$ & $\begin{array}{c}\text { Face-gear } \\
S / N\end{array}$ & $\begin{array}{c}\text { Pinion } \\
\text { S/N }\end{array}$ & $\begin{array}{c}\text { Face-gear } \\
\text { S/N }\end{array}$ \\
\hline 1 & 2300 & $242(64 \%)$ & 40.6 & 10.0 & L5-12 & $2-2$ & L5-5 & $2-4$ \\
\hline 2 & 2300 & $287(76 \%)$ & 40.6 & 10.0 & L5-12 & $2-2$ & L5-5 & $2-4$ \\
\hline 3 & 2300 & $332(88 \%)$ & 40.6 & 10.0 & ᄂ5-12 & $2-2$ & L5-5 & $2-4$ \\
\hline 4 & 2300 & $377(100 \%)$ & 40.6 & 10.0 & L5-11 & $2-2$ & L5-9 & $2-4$ \\
\hline 5 & 2300 & $424(112 \%)$ & 40.6 & 10.0 & 1 & $2-2$ & 2 & $2-4$ \\
\hline
\end{tabular}

number), the tooth contact approaches the outerdiameter edge of the face gear, again possibly leading to edge contact. In addition, the clearance between the pinion and face gear could be critically reduced when the gears reach operating temperature if the backlash is too tight. This could result in jamming, coast-side contact, or scoring failure. From the experience of the tests performed, backlash in the range of 0.178 to $0.254 \mathrm{~mm}(0.007$ to $0.010 \mathrm{in})$ produced acceptable tooth contact patterns.

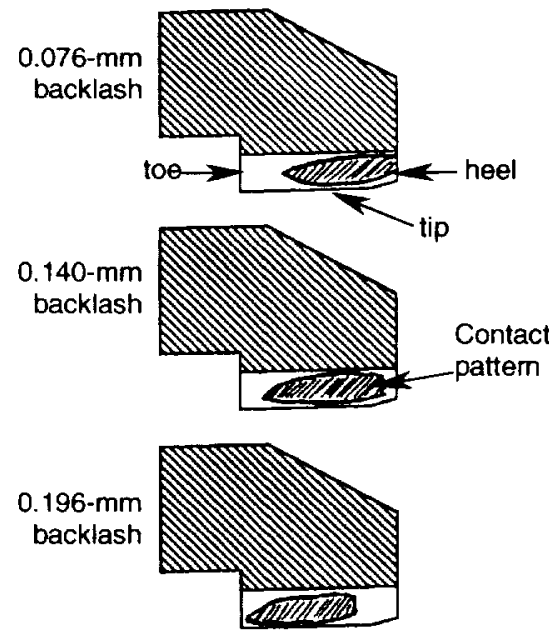

Figure 10. Effect of face-gear shimming and backlash on tooth contact pattern (test side face gear).

\section{Test Procedure}

A total of five endurance tests are reported in this work. The test operating conditions are listed in Table 2. The objective of the tests was to demonstrate that carburized and ground face gears would achieve the required durability when subjected to high-load helicopter transmission conditions. At the start of the project, extensive modal surveys of the test facility were conducted as well as speed sweeps with the test hardware installed. From these studies, a face gear speed of $2300 \mathrm{rpm}$ was selected as the test condition to avoid any speeds that could contain facility-resonant dynamic loads. Test gear loads of $64.76,88,100$, and 112-percent design torque were run for ten-million face-gear cycles each.
The same test-side face gear was used for all of the runs (serial number (S/N) 2-2). Similarly, the same slave-side face gear was used ( $/$ /N 2-4). These were carburized, ground, and super-finished face gears. Since the pinions accumulated over four times the number of cycles as the face gears, the pinions were replaced after each higher load condition to minimize the chance of a pinion failure causing face-gear tooth distress. Based on this, the pinions for both the test and slave sides were replaced after the 88 and 100-percent load tests. The original pinions (S/N's L5-12 and L5-5) were carburized, ground, and super-finished, while the subsequent ones used were only carburized and ground.

At the start of each test, the gears were installed as discussed in the previous section. They were then run for a break-in period which consisted of a gradual increase in speed and torque. After the break-in, the gears were visually inspected then run per the specified test condition. Facility parameters such as speed, torque, oil flow, oil pressure, temperatures, and vibration were monitored throughout the test. After completion of ten-million face-gear cycles, the gears were removed from the rig, inspected (visual and magnetic particle), and photographed.

\section{Results and Discussion}

Figure 11 shows typical vibration spectrums from the tests. The spectrums were produced from highfrequency piezoelectric accelerometers mounted on top of the pinion housings near the pinion/face-gear meshes. One was mounted on the test side and one on the slave side. The accelerometers had integral electronics, a typical sensitivity of $10 \mathrm{mV} / \mathrm{g}$, and a resonance frequency of $90 \mathrm{kHz}$. From the spectrum, the major sources of vibration were from the pinion/face-gear fundamental meshing and harmonic frequencies.

Figure 12 gives the maximum vibration as a function of run time for all the tests. The maximum vibration is defined as the maximum value of the spectrum, and usually occurred at the pinion/face-gear fundamental meshing frequency. Note that the vibration was rather sporadic during the tests. This is 

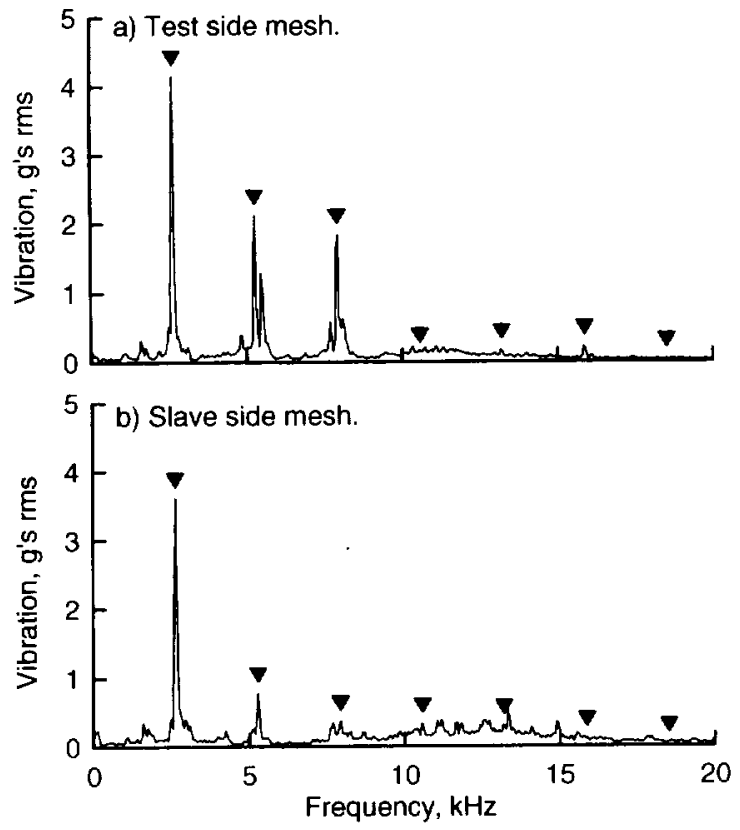

Figure 11. Vibration spectrum at 10-million face-gear cycles at $424 \mathrm{~N}-\mathrm{m}$ torque and $2300 \mathrm{rpm}$ (triangles denote pinion/face-gear meshing and harmonic frequencies).

not uncommon for vibration of high-speed machinery. Also, there appeared to be no definite trend of vibration with torque. This is consistent with previous studies performed on helicopter transmissions $[14,15]$. From Figure 12b, a significant reduction in vibration for the slave side occurred at 20 million cycles. This was probably due to the replacement of a failed pinion shaft support bearing at the end of test 2 . Also, significant changes in vibration occurred at 30 and 40 million cycles for both the test and slave sides (Figures 12a and 12b). This was probably due to installation of replacement pinions for tests 4 and 5 .

At the end of tests 1 and 2 (242 N-m, 64-percent design torque, and $287 \mathrm{~N}$-m, 76-percent design torque, respectively), there was no noticeable wear on any of the spur pinions or face gears. At the end of test 3 (332 N-m, 88-percent), the pinions had very light wear but the face gears exhibited no noticeable wear. The pinion teeth on the slave side had wear lines where the pinion meshed with the face-gear outer-diameter region. This was possibly caused by debris from the pinion shaft support bearing failure.

At the end of test $4(377 \mathrm{~N}-\mathrm{m}, 100$-percent $)$, the replacement pinions had a slight increase in the amount of wear compared to the pinions from test 3 . Concentrated wear on the pinion teeth was noticed as diagonal lines on the teeth corresponding to the location of the pitch line. The face gears, however,

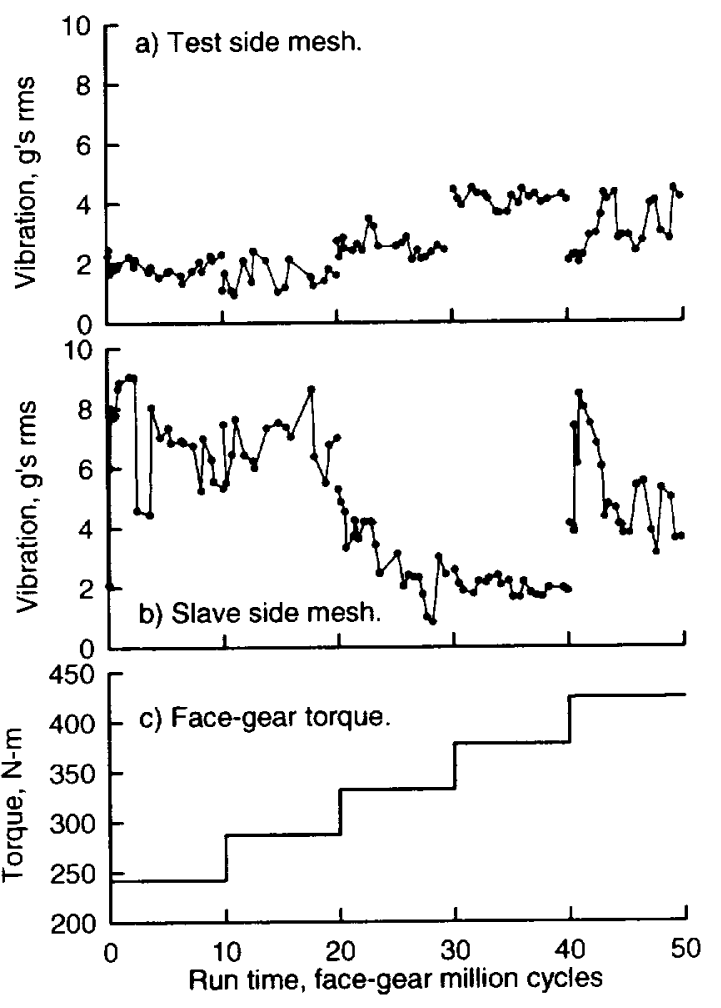

Figure 12. Maximum vibration of spectrum as a function of run time.

had less noticeable wear than the pinions. Slight wear lines were noticed that appeared to correspond with the edges of the facets on the teeth.

At the end of test 5 (424 N-m, 112-percent), the replacement pinions had again, a slight increase in the amount of wear compared to the pinions from test 4. This was expected due to the increased applied load. Slight wear lines were apparent near the pitch line as well as edge lines where the pinion meshed with the face-gear inner-diameter and outerdiameter regions. The marks corresponding to the face gear outer-diameter region were attributed to a few burrs on the face-gear outer-diameter edge, probably caused during hardware assembly. Slight scratching appeared at the tooth tips. Overall, however, relatively little wear was noticed. The face gears had even less noticeable wear than the pinions. As stated before, slight wear lines were noticed that appeared to correspond with the edge of the facets on the teeth. At this time, the effect of the facets on durability and performance are not known. Also, minor scratching was exhibited on the face gears near the outer-diameter tip region. Figure 1.3 depicts the wear after test 5. Aside from minor wear line situations, the pinions and, especially the face gears, had no significant wear problems or failure modes. (Note that the wear of the pinions in Figure 13 is just the removal of the black-oxide.) Thus, from the tests. 
the carburized and ground face gears demonstrated the required durability when subjected up to 112-percent design torque. Further tests are planned to increase the applied torque and determine the load capacity of the face gears.

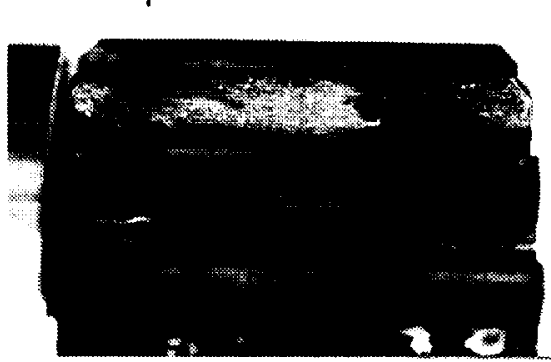

a) Pinion, test side.

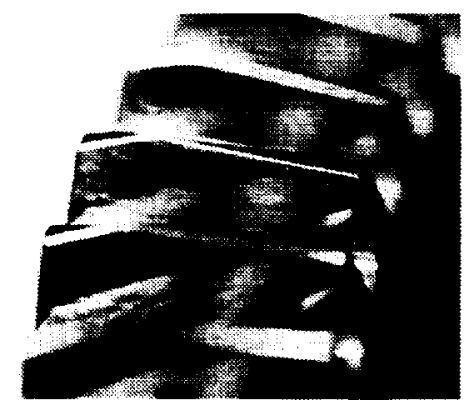

b) Face gear, test side.

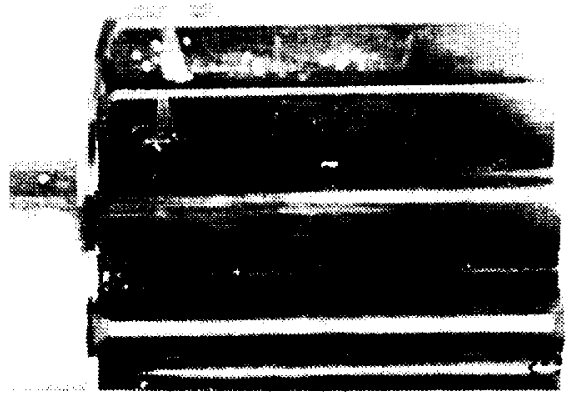

c) Pinion, slave side.

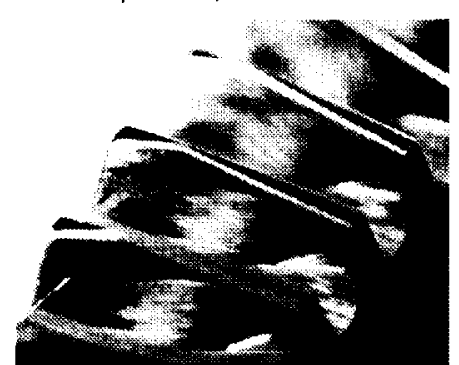

d) Face gear, slave side.

Figure 13. Pinion and face gear teeth after test 5 (424 N-m, 112-percent design torque).

\section{Conclusions}

Experimental durability tests were performed on carburized and ground AISI 9310 steel face gears. The tests were conducted in the NASA Glenn spiralbevel-gear/face-gear test facility. Tests were run at $2300 \mathrm{rpm}$ face gear speed and at loads of $64,76,88$, 100 , and 112-percent of the design torque of $377 \mathrm{~N}-\mathrm{m}$ (3340 in-lb) at ten-million face-gear cycles each. The following conclusions were made:

1) Carburized and ground face gears demonstrated the required durability when run for ten-million cycles at loads of $64,76,88,100$, and 112-percent of the design torque. Other than wear lines caused by isolated situations, the spur pinions and face gears had no significant wear problems or failure modes.

2) Proper installation was critical for the successful operation of the spur pinions and face gears. Backlash too high produced tooth contact patterns that approached the inner-diameter edge of the face-gear tooth. Backlash that was too low produced tooth contact patterns that approached the outer-diameter edge of the facegear tooth. Measured backlashes in the range of 0.178 to $0.254 \mathrm{~mm}(0.007$ to $0.010 \mathrm{in})$ produced acceptable tooth contact patterns.

3) From spectrum readings taken during the tests, the major source of vibration was from the pinion/face-gear fundamental meshing frequency and harmonics. Also, there was no definite trend of vibration with torque.

\section{References}

1. Heath, G.F., and Bossler, R.B., "Advanced Rotorcraft Transmission (ART) Program - Final Report", NASA CR-191057, Army Research Laboratory ARL-CR-14, January 1993.

2. Grendal, H.F., "Cylkro Gears: An Alternative in Mechanical Power Transmission", Gear Technology, Vol. 13, (3), May-June 1996, pp. 26-31.

3. AGMA, "Fine-Pitch On-Center Face Gears for 20-Degree Involute Spur Pinions", AGMA 203.03, April 1973. 
Public reporting burden for this collection of information is estimated to average 1 hour per response, including the time for reviewing instructions, searching existing data sources, gathering and maintaining the data needed, and completing and reviewing the collection of intormation. Send comments regarding this burden estimate or any olher aspect of this collection of intormation, including suggestions tor reducing inis burden, to Washington Heada

\begin{tabular}{l|l|l|l} 
Davis Highway, Suile 1204, Arlington, VA 22202-4302, and to the Office of Management and & 2. REPORT DATE & 3EPORT TYPE AND DATES COVERED
\end{tabular}

\begin{tabular}{|l|l|l}
\hline 1. AGENCY USE ONLY (Leave blank) & $\begin{array}{c}\text { 2. REPORT DATE } \\
\text { May } 1999\end{array}$ & $\begin{array}{r}\text { 3. REPORT TYPE AND DATES COVERED } \\
\text { Technical Memorandum }\end{array}$
\end{tabular}

4. TITLE AND SUBTITLE 5. FUNDING NUMBERS

Evaluation of Carburized and Ground Face Gears

6. AUTHOR(S)

WU-58I-30-13-00

$1 \mathrm{~L} 162211 \mathrm{~A} 47 \mathrm{~A}$

David G. Lewicki, Robert F. Handschuh, Gregory F. Heath, and Vijay Sheth

7. PERFORMING ORGANIZATION NAME(S) AND ADDRESS(ES)

NASA Glenn Research Center

Cleveland, Ohio 44135-3191

and

U.S. Army Research Laboratory

Cleveland, Ohio 44135-3191

9. SPONSORING/MONITORING AGENCY NAME(S) AND ADDRESS(ES)

National Aeronautics and Space Administration

Washington. DC 20546-0001

and

U.S. Army Research Laboratory

Adelphi. Maryland 2078.3-1145

11. SUPPLEMENTARY NOTES

Prepared for the 55th Annual Forum sponsored by the American Helicopter Society, Montreal, Quebec, Canada, May 25-27, 1999. David G. Lewicki and Robert F. Handschuh, U.S. Army Research Laboratory, NASA Glenn Research Center; Gregory F. Heath and Vijay Sheth, The Boeing Company, Mesa, Arizona. Responsible person, David G. Lewicki, organization code 5950, (216) 433-3970.

12a. DISTRIBUTION/AVAILABILITY STATEMENT

12b. DISTRIBUTION CODE

Unclassified - Unlimited

Subject Category: 37

Distribution: Nonstandard

This publication is available from the NASA Center for AeroSpace Information, (301) 621-0390.

13. ABSTRACT (Maximum 200 words)

Experimental durability tests were performed on carburized and ground AISI 9310 steel face gears. The tests were in support of a Defense Advanced Research Projects Agency (DARPA) Technology Reinvestment Program (TRP) to enhance face-gear technology. The tests were conducted in the NASA Glenn spiral-bevel-gear/face-gear test facility. Tests were run at $2300 \mathrm{rpm}$ face gear speed and at loads of 64,76, 88, 100, and 112-percent of the design torque of 377 $\mathrm{N}-\mathrm{m}(3340 \mathrm{in}-\mathrm{lb}$ ). The carburized and ground face gears demonstrated the required durability when run for ten-million cycles at each of the applied loads. Proper installation was critical for the successful operation of the spur pinions and face gears. A large amount of backlash produced tooth contact patterns that approached the inner-diameter edge of the face-gear tooth. Low backlash produced tooth contact patterns that approached the outer-diameter edge of the face-gear tooth. Measured backlashes in the range of 0.178 to $0.254 \mathrm{~mm}(0.007$ to $0.010 \mathrm{in})$ produced acceptable tooth contact patterns.

14. SUBJECT TERMS

Gears; Transmissions (machine elements); Durability; Face-gears

15. NUMBER OF PAGES 15

16. PRICE CODE

$\mathrm{A} 03$

\begin{tabular}{|c|c|c|}
\hline $\begin{array}{c}\text { 17. SECURITY CLASSIFICATION } \\
\text { OF REPORT } \\
\text { Unclassified }\end{array}$ & $\begin{array}{c}\text { 18. SECURITY CLASSIFICATION } \\
\text { OF THIS PAGE } \\
\text { Unclassificd }\end{array}$ & $\begin{array}{c}\text { 19. SECURITY CLASSIFICATION } \\
\text { OF ABSTRACT } \\
\text { Unclassified }\end{array}$ \\
\hline
\end{tabular}

NSN 7540-01-280-5500

Standard Form 298 (Rev. 2-89)

Prescribed by ANSI Std. Z39-18 298-102 
4. Chakraborty, J., and Bhadoria, B.S., "Surface Durability Ratings for On-Center and Off-Center Spur Face Gears", ASME 75-PTG-4, Joint ASLE-ASME Lubrication Conference, Miami Beach, FL, October 1975.

5. Litvin, F.L., et al., "Design and Geometry of Face-Gear Drives", ASME Journal of Mechanical Design, Vol. 114, (4), December 1992, pp. 642-647.

6. Litvin, F.L., et al., "Application of Face-Gear Drives in Helicopter Transmissions", ASME Journal of Mechanical Design, Vol. II6, (3), September 1994, pp. 672-676.

7. Toma, C., and Play, D., "Design of Face Gears: Manufacturing Simulation and Mechanical Behaviour", 7th International Power Transmission and Gearing Conference, San Diego, CA, October 1996, pp. 687-692.

8. Zhang, Y.. and Wu, Z., "Offset Face Gear Drives: Tooth Geometry and Contact Analysis", ASME Journal of Mechanical Design, Vol. 119 , (1). September 1997, pp. 114-119.

9. Handschuh, R.F., Lewicki, D.G., and Bossler, R., "Experimental Testing of Prototype Face Gears for Helicopter Transmissions", Journal of Aerospace Engineering, Proceedings of the Institute of Mechanical Engineers, Vol. 208, (G2), October 1994, pp. 129-135.

10. Handschuh, R.F., Lewicki, D.G., Heath, G.F., and Bossler, R.B., "Experimental Evaluation of Face Gears for Aerospace Drive System Applications", 7th International Power Transmission and Gearing Conference, San Diego, CA, October 1996, pp. 581-588.
11. Caruso, A., et al., "The Brite-Euram FACET Programme on Face Gears in Aerospace Transmissions", Aerospace Transmission Technology Into the 21st Century, Cascina Costa, Italy, October 1998.

12. Chen, D., and Bossler, R.B., "Design, Analysis, and Testing Methods for a Split-Torque FaceGear Transmission", 31st AIAA/SAE/ASME Joint Propulsion Conference, San Diego, CA. July 1995.

13. Snidle, R.W., Evans, H.P., and Alanou, M.P., "The Effect of Superfinishing on Gear Tooth Profile [Final Report]". Army Research Development and Standardization Group Report AD-A327916, June 1997.

14. Lewicki, D.G., and Coy, J.J., "Vibration Characteristics of OH-58A Helicopter Main Rotor Transmission", NASA TP-2705, AVSCOM TR-86-C-42, April 1987.

15. Lewicki, D.G., Handschuh, R.F., Henry, Z.S., and Litvin, F.L.. "Low-Noise, High-Strength, Spiral-Bevel Gears for Helicopter Transmissions", AIAA Journal of Propulsion and Power, Vol. 10, (3), May-June 1994, pp. 356-361. 